\title{
Teamwork competence assessment
}

\author{
E Viles*, C Jaca*, M Zárraga-Rodríguez** \\ * Tecnun (University of Navarra) \\ ** ISSA (University of Navarra)
}

\begin{abstract}
Teamwork is an important competence to be developed among students and this paper presents a case study related with teamwork competence assessment and development. Several processes take place during team assignment among students. We consider that the development of teamwork competence is related with being efficient in those processes. From a literature review of the processes that arise during teamwork, we present a evaluation tool which includes formative feedback in order to help students to target their own teamwork competence development. By providing students with guidelines for improvement, it seems reasonable to expect a better performance in subsequent experiences and thus it is also reasonable to assume the progressive competence development. A total of 58 teams from a Bachelor's Degree Programme in Industrial Engineering have been evaluated with this tool and therefore some conclusions are presented.
\end{abstract}

Keywords: Teamwork, competences, higher education

\section{Introduction}

Under the new European Higher Education Area it has been necessary to design learning and evaluation models in accordance with the Bologna guidelines which imply moving from acquiring knowledge to developing competences. In particular, in this paper, we are focused on teamwork competence and its development.

Students' teamwork competence is not developed just by working together on an assignment and involves the acquisition of different skills. Moreover, teamwork competence is obtained through a process that is difficult to tackle if students do not receive justified feedback on their performance as part of work teams (Marin-Garcia et al., 2008, Martinez-Gomez \& Marin-Garcia, 2009). This feedback will help the students to improve their performance in next team assignments. Students' acquisition of teamwork competence is a continuous and progressive process. Teachers should monitor this process and, in order to assess teamwork competence development, evidences regarding students' performance during their learning experiences need to be collected and analyzed.

During a team assignment among students several processes take place. According to the literature review, those processes are participation, conflict management, problem solving, internal communication / mutual respect / trust, external communication / feedback, collaboration / cooperation and leadership. We consider that to the extent that the students are efficient in relation to those processes, their teamwork competence development is enabled. There already exists a tool for assessing the performance of the team regarding those processes (Viles et al., 2013). In this work we are focused on the assessment of the individual performance of each student.

Usually, the teacher tries to assess the individual performance of each student; however nobody argues today about the need of finding new ways to assess competences taking into account not only the teachers' perceptions but also the perceptions of the others agents involved in teamwork, i.e., the students. In order to evaluate students' performance the use of peer ratings and self-evaluations are evidenced to be useful techniques that will help students to improve their individual performance. In this context the paper present a case study related with the assessment of teamwork 
competence among students. We present a tool that allows self-assessment and peer evaluation of students' performance during a team assignment. It also allows giving formative feedback to the students on their performance as part of work teams. By providing students with this formative evaluation, it seems reasonable to expect a better performance in subsequent experiences and thus it is also reasonable to expect the progressive competence development.

A total of 224 students involved in 58 teams from a Bachelor's Degree Programme in Industrial Engineering participated in the case study and some conclusions from this experience are presented.

\section{Conceptual framework}

\section{Self-assessment and peer review}

Self-assessment and peer review have been deployed in some areas of education for many years. The disciplines areas where this type of assessment is used are varied and it is used across a very wide range of educational stages, from school to higher education and even in professional post courses. While some authors discuss about the lack of reliability or validity of this type of assessments, in contrast, others mention that formative assessment can help students to plan their own learning, identifying their own strengths and weaknesses, in order to direct their efforts to specific areas for improvement actions and to develop other personal and professional skills (Boud et al., 1990; Boud \& Fachikov, 2006; Falchikov \& Goldfinch, 2000; Brown \& Knight, 2004; Topping, 2003).

Regarding teamwork, some authors have provided valuable research on the assessment of team members (Chalupa,Chen \& Sormunen-Jones, 2000; Gueldenzoph \& May, 2002). Specifically, Gueldenzoph and May (2002) mention some best practices in order to achieve and effective evaluation process. Creating an effective evaluation tool and implementing formative feedback are some critical aspects which have to be taken into account. Crews and North (2000) suggest that formative evaluation should be conducted throughout collaborative experience. Peer ratings help students to develop teamwork competence (Oakley eta al., 2004) and anonymous peer feedback is recommended as a way to shape members' teamwork skills (Parratt et al.,2014). If students can receive continual feedback on their team performance, group members could modify their behavior as necessary to assure the correct acquisition of the competence.

\section{Processes that arise during teamwork}

Several processes occur during teamworking and affect the team performance and its effectiveness. These processes are divided into two groups: operational processes and emergent states (Markset al., 2001). Operational processes are included in the different models of teamwork (Cohen \& Bailey, 1997; Kozlowski \& Ilgen, 2006; Mathieu, Heffner, Goodwin, Cannon-Bowers, \& Salas, 2008, McGrath, 1964). These processes describe functions and interactions that occur during teamwork and how they are managed in order to perform team tasks (OP1-OP7). Emerging states consist of motivational processes that capture trends, relationships between team members and affective reactions (ES1-ES4). These processes involve a dynamic display, which tends to be stable over time (Kozlowski \& Ilgen, 2006). Our understanding of these processes is consistent with the proposals of different authors as shown below. 
OP1: Participation - refers to the extent to which team members have an active role in the development of the work and how decisions are made. (DeDreu \& West, 2001; Sheppard et al., 2004)

OP2: Conflict management - refers to how conflicts are valued in the team and if they are properly managed. (Bolton, 1999; Kozlowski \& Ilgen, 2006; Oakley et al., 2007; Sheppard et al., 2004).

OP3: Problem solving - refers to the ability to solve problems, which is related to the team's goal of improving. (Sheppard et al., 2004; Thylefors et al., 2005).

OP4: Internal communication / mutual respect / trust - is in relation with proper and effective communication. (Brooks \& Ammons, 2003; Delson, 2001; Oakley et al., 2007; Sheppard et al., 2004; Zander, 1994).

OP5: External communication and feedback - refers to the extent to which the team has access to information and is duly listened to by the organization. (Delson, 2001; Oakley et al., 2007; Seat \& Lord, 1999).

OP6: Collaboration and cooperation - refers to the extent to which team members work on a voluntary basis to achieve the objectives that have been established. (Gratton \& Erickson, 2007; Lopez-Paniagua et al., 2011.).

OP7: Leadership - refers to the internal team leader ( Zaccaro et al., 2001).

ES1: Team Learning. This learning refers to knowledge embedded within the team (Edmondson, 1999). The capabilities accumulate and improve as team members accrue experiences and learn how to work together better (Kozlowski \& Ilgen; 2006).

ES2: Team climate. Climate refers to "the set of norms, attitudes and expectations that individuals perceive to operate in a specific social context.” (Pirola-Merlo et al., 2002). Creating a positive team climate implies creating conditions and an atmosphere in which individuals can speak up and express concerns (Leonard et al., 2004).

ES3: Mutual trust. Trust in a team is the shared belief that team members will perform their roles and protect the interests of their teammates (Salas et al., 2005).

ES4: Motivation. Motivation is related with the sense of collective confidence and taskbased cohesion with regard to mission accomplishment (Marks et al., 2001). This includes encouraging team members to perform better or to maintain high levels of performance by communicating their beliefs about team ability, competence in particular tasks and being leaders involved with the development of the project. (Guzzo \& Dickinson, 1996).

\section{Case study}

The case study presented in this paper was designed to assist the development of students' teamwork competence. For this purpose we both measured students' individual performance and provided such information to students involved. Moreover, a proposal of actions leading to improve that performance was also provided to the students.

A total of 224 students were involved in the experience, who were attending at the firstyear subject of a Bachelor's Degree Programme in Industrial Engineering. In this subject, students had to do an assignment in groups of 4 members and therefore a total of 58 teams took part in the case study. 
Once students had completed the assignment each student was asked to individually rate their own performance and the performance of each of his teammates. Items in the questionnaire used to collect the data were defined taking into account several proposals (Viles et al., 2013; Oakley et al., 2007; Gueldezoph \& May, 2002 among others). The questionnaire was developed in a web platform and the link to the questionnaire was sent to the students via mail. The aim of the questionnaire and how to answer it (instructions and dates) were also explained in the mail. As a condition to know the final mark of the assignment, each student had to respond to the questionnaire.

\section{The Tool}

To measure student performance, we elaborated an evaluation tool based on a questionnaire which evaluates the student performance within the team from both their own point of view and the point of view of the other team components. From data collected in the questionnaires we draw a individual student performance radar graph. To provide adequate feedback to the student, each student received an evaluation file with his or her individual radar graph together with a set of guidelines for teamwork competence improvement.

The questionnaire was designed to assess the operational processes that arise once a team is working on an assignment. Although the analysis of the teamwork emerging states would be also interesting, it is quite difficult to evaluate. On one hand, the establishment of scales in this case is more complex. On the other hand, the literature indicates that emerging states tend to stabilize over time as the teams remain (Ilgen et al., 2005; Mathieu et al., 2008), and this characteristic hardly occurs in a degree or teaching cycle where the teams often are exclusively formed for a particular assignment. Therefore, the questionnaire measures only the operational processes, not the emerging states.

Table 1 presents the specific items in the questionnaire related with the operational processes they aimed to assets using a scale from 1(never) to 5 (always).

Table 1. Operational processes and items in the questionnaire

\begin{tabular}{|c|c|}
\hline Process & Items in the questionnaire \\
\hline \multirow{3}{*}{ OP1: Participation } & The student has attended team meetings punctually. \\
\hline & $\begin{array}{l}\text { The student has assumed and performed the role and the tasks that } \\
\text { have been assigned to him. }\end{array}$ \\
\hline & The student has actively participated in decision making. \\
\hline OP2: Conflict management & $\begin{array}{l}\text { The student has exposed his opinion in an impartial and constructive } \\
\text { way }\end{array}$ \\
\hline OP3: Problem solving & $\begin{array}{l}\text { The student has analyzed problem information and has proposed } \\
\text { solutions }\end{array}$ \\
\hline \multirow{2}{*}{$\begin{array}{l}\text { OP4: Internal } \\
\text { communication / mutual } \\
\text { respect / trust }\end{array}$} & $\begin{array}{l}\text { The student has paid attention to the opinion of his teammates with } \\
\text { respect for them }\end{array}$ \\
\hline & $\begin{array}{l}\text { The student has been open-minded to different ways of thinking and } \\
\text { working }\end{array}$ \\
\hline $\begin{array}{l}\text { OP5: External } \\
\text { communication and } \\
\text { feedback }\end{array}$ & The student is aware of external factors that may affect the teamwork \\
\hline
\end{tabular}




\begin{tabular}{ll}
\hline Process & Items in the questionnaire \\
\hline $\begin{array}{l}\text { OP6: Collaboration and } \\
\text { cooperation }\end{array}$ & $\begin{array}{l}\text { The student has made contributions in team meetings } \\
\text { The student has cooperated with the overall team effort (analysis, } \\
\text { resolution and completion of the report) }\end{array}$ \\
\hline OP7: Leadership & The student has been the leader planning and organizing the team
\end{tabular}

Once the questionnaires were fulfilled, data collected were processed in order to obtain for each student and for each process the following information: auto-assigned score and an average of the scores given by his teammates. This information was summarized using individual radar graphs which were delivered to students in a document or file. The radar graph allowed the student to compare his own perception with the perceptions of his teammates about his performance. Every student knows the average of the scores assigned by their peers; therefore, anonymity in response is guaranteed.

Figure 1 shows an example of an individual radar graph together with some guidelines for teamwork competence improvement.

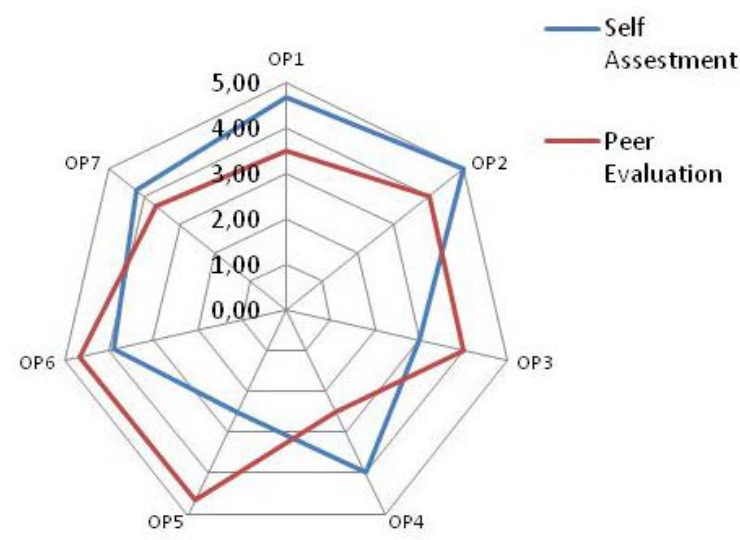

\section{Guidelines for teamwork competence improvement}

OP4: Give your opinion respecting others turns.

OP5: look for dialogue with the teacher in order to receive feedback about the work.

Figure 1. Individual radar graph and guidelines

\section{Results}

To assess the students' opinion about the new evaluation tool, we asked them about its usefulness.

They were asked about the feedback they had received (understandability and usefulness of the evaluation file). They were also asked whether they considered the information provided useful guide for improving their individual teamwork competence in future team assignments that they will have to face with throughout the degree. Both questions should be rated between 1 (very unclear / useless) to 5 (very light / useful). At the same time, they could make any comment about the effectiveness of the evaluation process. 
Table 2. Data collected

\begin{tabular}{lcccccccc}
\hline Variable & $\mathrm{n}$ & Mean & StDev & Minimun & Q1 & Median & Q3 & Maximun \\
\hline Understandably & $81(35 \%)$ & 3,81 & 0,85 & 1 & 3 & 4 & 4 & 5 \\
Usefulness & $77(33 \%)$ & 4,17 & 0,7 & 3 & 4 & 4 & 5 & 5 \\
\hline
\end{tabular}

The 34\% of students who participated in this study answered to this survey. Table 2 summarizes collected information. From these data we can observe that students scored high both understandably and usefulness. It should also be noted the broad acceptance among students this information has had. The students received as something positive the result of their assessment and their comments were in general that the feedback received could help them to improve. The majority of comments referred to the importance of having information from their peer teammates. As opposed to other authors we have not detect rejection towards this type of assessment.

\section{Conclusions}

The new educational models aimed at developing competencies also lead to the need to assess the degree of acquisition of them. Therefore, for competences development it is necessary to provide supervised learning experiences to the students throughout the degree. These learning experiences have to be monitored and students have to receive feedback that leads them to achieve better performance in the following experience which they face with. Giving each student their individual radar graph along with a list of guidelines for teamwork competence improvement can facilitate understanding, monitoring and improving the individual performance in team projects/assignments and it can lead to a progressive acquisition of teamwork competence by each student.

To the extent that this method is used in others team projects/assignments throughout the degree it will allow student to collect evidences of their teamwork competence development along the whole degree.

Future studies could pass the questionnaire during the course in order to analyse the impact of the feedback on their team learning experiences.

\section{References}

Bolton, M. K. (1999). The role of coaching in student teams: A "just-in-time" approach to learning. Journal of Management Education, 23(5), 467-488.

Boud D., Cohen R. \& Sampson J. (1999) Peer Learning and Assessment. Assessment \& Evaluation in Higher Education, 24(4), 413-426.

Boud D. \& Falchikov N. (2006) Aligning assessment with long-term learning. Assessment \& Evaluation in Higher Education. 31 (4), 399-413.

Brooks, C. M., \& Ammons, J. L. (2003). Free riding in group projects and the effects oftiming, frequency, and specificity of criteria in peer assessments. Journal of Education for Business, 78(5), 268-272.

Brown S. \& Knight P. (2004) Assessing Learners in Higher Education. Teaching and Learning in Higher Education Series. Series Editor: John Stephenson. British Library. ISBN 0749411139

Chalupa, M. R.; Chen, C. S. \& Sormunen-Jones, C. (2000). Reliability and Validity of the Group Member Rating Form. Delta Pi Epsilon Journal, 42 (4), 235-245. 
Cohen, S. G., \& Bailey, D. E. (1997). What makes teams work: Group effectiveness research from the shop floor to the executive suite. Journal of Management, 23(3), 239-290.

Crews and North (2000) Team evaluation (Part2 of 2). Instructional Strategies, 16 (2), 1-4.

Dedreu, C. K. W., \& West, M. A. (2001). Minority dissent and team innovation: The importance of participation in decision making. Journal of Applied Psychology, 86(6), 1191-1201.

Delson, N. (2001). Increasing team motivation in engineering design courses. International Journal of Engineering Education, 17(4-5), 359-366.

Edmondson, A. (1999). Psychological safety and learning behavior in work teams. Administrative Science Quarterly, 44(2), 350-383.

Falchikov, N. \& Goldfinch, J. (2000) Student Peer Assessment in Higher Education: A Meta-Analysis Comparing Peer and Teacher Marks. Review of Educational research, 70 (3), 287-322.

Gratton, L. \& Erickson, T. J. (2007). Eight ways to build collaborative teams. Harvard Business Review, vol.85, núm11: 100-109.

Gueldenzoph, L.E. \& May G.L. (2002). Collaborative Peer Evaluation: Best Practices for Group Member Assessments. Business Communication Quarterly, 65(1), 9-20.

Guzzo, R. A. \& Dickinson, M. W. (1996). Teams in organizations: Recent research on performance and effectiveness. Annual Review of Psychology, 47, 307-338.

Ilgen, D. R., Hollenbeck, J. R., Johnson, M., \& Jundt, D. (2005). Team in organizations: From inputprocess-output models to IMOI models. Annual Revision Psychologist, 56, 517-543.

Kozlowski, S. W. J., \& Ilgen, D. R. (2006). Enhancing the effectiveness of work groups and teams. Psychological Science in the Public Interest, 7(3), 77-124.

Leonard, M., Graham, S., \& Bonacum, D. (2004). The human factor: The critical importance of effective teamwork and communication in providing safe care. Quality Safety in Health Care, 13, I85-I90.

Lopez-Paniagua, I., Nieto-Carlier, R., Rodriguez-Martin, J., Gonzalez-Fernandez, C., \& Jimenez-Alvaro, A. (2011). Practical sessions: A key tool for teaching in the European higher education area framework. Dyna, 86(5), 523-530.

Marin-Garcia, J. A., Miralles-Insa, C., García-Sabater, J. J., \& Vidal-Carreras, P., I. (2008). Enseñando administración de empresas con docencia basada en el trabajo en equipo de los estudiantes: Ventajas, inconvenientes y propuestas de actuación. Intangible Capital, 4(2), 143-165.

Marin-Garcia, J. A., Garcia-Sabater, J. P., Perello-Marin, M. R., \& Canos-Daros, L. (2009). Propuesta de competencias para el ingeniero de organización en el contexto de los nuevos planes de estudio. Intangible Capital, 5(4), 387-406.

Marks, M., Mathieu, J. E., \& Zaccaro, S. (2001). A temporally based framework and taxonomy of team processes. The Academy of Management Review, 26(3), 356-376.

Mathieu, J. E., Maynard, M. T., Rapp, T., \& Gilson, L. (2008). Team effectiveness 1997-2007: A review of recent advancements and a glimpse into the future. Journal of Management, 34(3), 410-476.

Mathieu, J. E., Heffner, T. S., Goodwin, G. F., Salas, E., \& Cannon-Bowers, J. A. (2000). The influence of shared mental models on team process and performance. Journal of Applied Psychology, 85, 273-283

Mcgrath, J. E. (1964). Social psychology: A brief introduction. New York: Holt, Rinehart \& Winston.

Mickan, S., \& Rodger, S. (2000). Characteristics of effective teams: A literature review. Australian Health Review, 23(3), 201-208.

Oakley, B. A., Hanna, D. M., Kuzmyn, Z., \& Felder, R. M. (2007). Best practices involving teamwork in the classroom: Results from a survey of 6435 engineering, student respondents. IEEE Transactions on Education, 50(3), 266-272.

Parratt, J. A.; Fahy, K. M.; Hastie, C. R.(2014). Midwifery students' evaluation of team-based academic assignments involving peer-marking. Women and Birth, 27(1), 58-63. 
Pirola-Merlo, A., Härtel, C., Mann, L., \& Hirst, G. (2002). How leaders influence the impact of affective events on team climate and performance in R\&D teams. The Leadership Quarterly, 13(5), 561-581.

Salas, E., Sims, D. E., \& Burke, C. S. (2005). Is there a "big five" in teamwork? Small Group Research, 36(5), 555-599.

Seat, E., \& Lord, S. M. (1999). Enabling effective engineering teams: A program for teaching interaction skills. Journal of Engineering Education, 88(4), 385-390.

Sheppard, K., Dominick, P., \& Aronson, Z. (2004). Preparing engineering students for the new business paradigm of international teamwork and global orientation. International Journal of Engineering Education, 20(3), 475-483.

Steiner, M., Kanai, J., Hsu, C., Alben, R., \& Gerhardt, L. (2011). Holistic assessment of student performance in multidisciplinary engineering capstone design projects. International Journal of Engineering Education, 27(6), 1259-1272.

Thylefors, I., Persson, O., \& Hellström, D. (2005). Team types, perceived efficiency and team climate in swedish cross-professional teamwork. Journal of Interprofessional Care, 19(2), 102-114.

Topping, K. (2003) Self and Peer Assessment in School and University: reliability, Validity and Utility. Optimising New Modes of Assessment: In Search of Qualities and Standards. Innovation and Change in Professional Education, 1, 55-87.

Viles, E., Zárraga-Rodríguez, M. \& Jaca, C. (2013) Herramienta para evaluar el funcionamiento de los equipos de trabajo en entornos docentes . Intangible Capital, 9(1): 281-304.

Zaccaro, S. J., Rittman, A. L., \& Marks, M. A. (2001). Team leadership. The Leadership Quarterly, 12(4), 451-483.

Zander, A. (1994). Making Groups Effective. San Francisco: Oxford: Ed.Jossey-Bass. 